JURNAL GIZI DAN DIETETIK INDONESIA

Vol. 4, No. 3, September 2016: 154-160
Tersedia online pada: http://ejournal.almaata.ac.id/index.php/IJND DOI : http://dx.doi.org/10.21927/ijnd.2016.4(3).154-160

\title{
Analisis determinan stunting pada baduta di wilayah kerja puskesmas tahun 2016
}

\author{
Determinant analysis of stunting of children under-two years (baduta) in Puskesmas 2016
}

\author{
Basri Aramico', Zamratul Husna ${ }^{1}$
}

\begin{abstract}
Backgrounds: The high prevalence of stunting and its impact on IQ decline makes stunting as one of the nutritional problems that should receive attention from various stakeholders. Optimal growth can only be achieved by the intake of nutritious food and healthy environment. In 2013, the prevalence of stunting in Aceh amounted to $37.2 \%$ consisted of $18 \%$ very short and $19.2 \%$ short. Based on the result of monitoring nutritional status report from Public Health Office in Pidie Jaya, the prevalence of stunting increased in the last two years. That percentage increased from 14.8\% in 2014 and become 17\% in 2015.

Objectives: This study aims to investigate the determinant of stunting in children under-two years (BADUTA) in Puskesmas Ulim, Pidie Jaya district in the year of 2016.

Methods: This research design is descriptive analytic by cross-sectional. The population in this study is all mothers who have BADUTA in Puskesmas Ulim in total of 75 respondents. The sampling method used was cluster sampling with total samples taken by $20 \%$ of the entire population from every six village among 30 villages. The primary data obtained directly by measuring the length of the child's body and interview using questionnaires. The statistical test used is Chi-Square Test.

Results: The study showed that $66.7 \%$ children experienced stunting, $70.7 \%$ children had lower dietary intake, $85.3 \%$ children did not receive exclusive breastfeeding, $8.0 \%$ children experienced low birth weight (LBW), and $80.0 \%$ had infectious diseases. Based on statistical analysis it can be concluded that there were relationship between nutrient intake $(p$-value $=0.000)$, breastfeeding $(p$-value $=0.000)$, and infectious diseases $(p$-value $=0.029)$ with stunting. However, there was no relation between low birth weight $(L B W)$ $(p$-value $=0.079)$ with stunting.

Conclusions: There were significant correlation between nutrition, exclusive breastfeeding, infection disease with stunting of BADUTA meanwhile there was no significant correlation between LBW babies with stunting in Puskesmas Ulim at Pidie Jaya district.
\end{abstract}

KEYWORDS: stunting, nutrient intake, exclusive breastfeeding, LBW, and infectious diseases

\begin{abstract}
ABSTRAK
Latar belakang: Stunting masih menjadi masalah yang harus diperhatikan pemerintah, karena anak penderita stunting mangalami penurunan intelligence quotient (IQ) dibandingkan dengan anak yang tidak stunting. Pertumbuhan yang optimal hanya dapat dicapai dengan asupan makanan yang bergizi serta lingkungan yang sehat. Pada tahun 2013 prevalensi stunting di Aceh sebesar 37,2\% terdiri dari 18,0\% sangat pendek dan 19,2\% pendek. Berdasarkan hasil laporan pemantau status gizi Dinas Kesehatan Kabupaten Pidie Jaya prevalensi stunting mengalami peningkatan dakam dua tahun terakhir. Persentase peningkatan tersebut pada tahun 2014 sebesar 14,8\%, meningkat menjadi 17\% pada tahun 2015.

Tujuan: Untuk menganalisis determinan stunting pada baduta di Wilayah Kerja Puskesmas Ulim Kabupaten Pidie Jaya tahun 2016.

Metode: Penelitian ini adalah penelitian deskriptif analitik dengan desain cross sectional. Populasi pada penelitian ini adalah seluruh ibu yang memiliki baduta di Wilayah Kerja Puskesmas Ulim sebanyak 75 responden, dengan metode cluster sampling. Sampel yang diambil sebesar $20 \%$ dari seluruh populasi, menggunakan teknik gugus dengan mengambil 6 desa dari 30 desa. Data primer diperoleh langsung
\end{abstract}

\footnotetext{
${ }^{1}$ Fakultas Kesehatan Masyarakat. Universitas Muhammadiyah Aceh, e-mail: Basri.aramico@yahoo.com
} 
melalui pengukuran panjang badan anak dan melalui kuesioner dengan cara wawancara. Uji statistik yang digunakan yaitu uji chi-square test.

Hasil: Sebanyak 66,7\% anak mengalami stunting, 70,7\% asupan gizi yang kurang, 85,3\% tidak mendapatkan ASI eksklusif, 8,0\% berat lahir rendah, dan 80,0\% mengalami penyakit infeksi. Hasil analisis statistik menunjukkan ada hubungan antara asupan gizi $(p=0,000)$, pemberian $A S I(p=0,000)$, dan penyakit infeksi $(p=0,029)$ dengan stunting. Namun tidak ada hubungan antara berat bayi lahir rendah $(p=0,079)$ dengan stunting pada baduta.

Kesimpulan: Ada hubungan antara asupan gizi, pemberian ASI ekslusif, penyakit infeksi dengan stunting pada baduta, dan tidak ada hubungan antara bayi berat lahir rendah dengan stunting pada baduta di Wilayah Kerja Puskesmas Ulim Kabupaten Pidie Jaya.

KATA KUNCI: stunting, asupan gizi, ASI eksklusif, BBLR, penyakit infeksi

\section{PENDAHULUAN}

Stunting adalah status gizi yang didasarkan pada indeks panjang badan menurut umur ( $\mathrm{PB} / \mathrm{U})$ atau tinggi badan menurut umur (TB/U) yang merupakan padanan istilah stunted (pendek) dan severely stunted (sangat pendek). Seorang anak yang mengalami kekerdilan sering terlihat seperti anak dengan tinggi badan normal untuk anak seusianya. Stunting dapat dipengaruhi oleh status gizi sebelum kelahiran,yang disebabkan oleh status gizi ibu yang kurang baik selama kehamilan, pola makan ibu hamil yang kurang tepat, kualitas makanan yang kurang baik, dan intensitas penyakit infeksi (1).

Stunting juga dapat dipengaruhi oleh berat bayi berat lahir rendah (BBLR), pola makan yang tidak sehat, kurangnya pemberian ASI, akibat penyakit infeksi pada masa balita, serta tidak tercapainya perbaikan pertumbuhan yang sempurna pada masa berikutnya. Oleh sebab itu tidak heran apabila banyak ditemukan anak yang stunting. Tidak hanya pada fisik yang pendek saja, stunting berpengaruh juga pada fungsi kognitifnya yaitu fungsi psikis dan tingkat beradaptasi dengan lingkungan sosialnya. Efek yang banyak ditemukan pada anak yang menderita stunting berat memiliki IQ 2 poin lebih rendah dibandingkan rata-rata anak yang tidak stunting. Hal ini mengakibatkan penurunan intelegensia (IQ), sehingga prestasi belajar menjadi rendah. Stunting tidak hanya berdampak pada fisik yang lebih pendek saja, tetapi juga pada kecerdasan, produktivitas, dan prestasi belajar. Hal ini dapat mempengaruhi potensi kualiatas sumber daya manusia (2).
Faktor-faktor yang dapat menyebabkan stunting di antaranya adalah pola makan, pemberian ASI ekslusif, kejadian BBLR, dan penyakit infeksi. Pola makan anak sangat erat hubungannya dengan pertumbuhan anak. Semakin baik pola makan anak maka semakin baik pertumbuhan anak. Sebaliknya anak yang pola makannya kurang baik dapat menyebabkan pertumbuhan anak terhambat sehingga anak berisiko mengalami stunting. Secara langsung, keadaan zat gizi dipengaruhi oleh kecukupan asupan makanan dan keadaan individu (3).

Prevalensi peningkatan stunting masih menjadi perhatian di Provinsi Aceh. Berdasarkan laporan Riskesdas tahun 2013 (4), sekitar 42,5\% anak di Provinsi Aceh mengalami stunting. Angka ini menunjukkan nilai lebih besar dibandingkan dengan angka prevalensi nasional yaitu $37,2 \%$. Di wilayah Kerja Puskesmas Ulim Kabupaten Pidie Jaya, prevalensi stunting mengalami kenaikan dalam dua tahun terakhir, yaitu pada tahun 2014 sebesar 14,33\% dan tahun 2015 sebesar 16,91\% (5). Penelitian ini bertujuan untuk menganalisis determinan stunting pada baduta di wilayah kerja Puskesmas Ulim Kabupaten Pidie Jaya tahun 2016.

\section{BAHAN DAN METODE}

Penelitian ini adalah penelitian observasional analitik dengan desain cross sectional. Penelitian dilaksanakan di Wilayah Kerja Puskesmas Ulim, Kabupaten Pidie jaya, Aceh pada bulan maret-April 2016. Populasi pada penelitian ini adalah seluruh baduta di Wilayah Kerja Puskesmas Ulim sebanyak 
75 responden, dengan metode sampling yang dipilih adalah cluster sampling. Sampel yang diambil sebesar $20 \%$ dari seluruh populasi menggunakan teknik gugus, yaitu dengan mengambil 6 diantara 30 desa. Teknik sampling yang digunakan adalah proportionate stratified random sampling, yaitu pengambilan sampel acak stratifikasi yang dilakukan secara proposional.

Data primer panjang badan anak diperoleh dengan cara pengukuran langsung, pengukuran asupan gizi diperoleh dengan instrument food recall untuk memperoleh data kecukupan energi dan protein . Data pemberian ASI ekslusif dan berat badan bayi lahir serta penyakit infeksi didapatkan melalui wawancara menggunakan kuesioner yang diadopsi dari penelitian Aramico, Dkk (6). Data berat badan bayi lahir diperoleh melalui pengamatan pada buku Kesehatan Ibu dan Anak (KIA). Uji statistik yang digunakan yaitu uji chi-square test.

Kategori analisis variabel penelitian terdiri dari asupan gizi (energi) yaitu asupan gizi kurang jika asupan energi dan protein $<80 \%$ kebutuhan dan cukup jika asupan $\geq 80 \%$ kebutuhan. Pemberian ASI eksklusif jika anak diberikan ASI saja sejak umur 0-6 bulan dan tidak eksklusif jika anak tidak hanya diberikan ASI sejak umur 0-6 bulan BBLR jika berat bayi lahir di bawah $2.500 \mathrm{gr}$ dan normal jika bayi lahir $\geq 2.500$ gr. Penyakit infeksi diare, ISPA, malaria, dan kecacingan merupakan hasil yang dikumpulkan melalui kuesioner, dan ditentukan dengan mengategorikannya: penderita penyakit infeksi jika hasil wawancara menunjukkan bahwa responden menderita salah satu penyakit infeksi tersebut dan dikategorikan, bukan penderita penyakit infeksi jika hasil wawancara menunjukkan tidak terinfeksi penyakit tersebut.

\section{HASIL}

\section{Karakteristik subjek penelitian}

Subjek pada peneltian ini adalah baduta yang berusia lebih dari 6 (enam) bulan sampai dengan anak berusia kurang dari 24 bulan (kurang dari 2 tahun), yang berjenis kelamin laki-laki dan perempuan. Pemilihan subjek penelitian yang berusia lebih dari 6 bulan dilakukan untuk memastikan bahwa subjek penelitian sudah melewati periode pemberian ASI eksklusif, sehingga dapat dikategorikan menjadi baduta yang mengonsumsi ASI eksklusif atau ASI non eksklusif.

Tabel 1. Distribusi frekuensi karakteristik subjek penelitian

\begin{tabular}{lll}
\hline \multicolumn{1}{c}{ Karakteristik } & $\mathbf{n}$ & $\mathbf{\%}$ \\
\hline $\begin{array}{l}\text { Jenis kelamin } \\
\quad \text { Laki-laki }\end{array}$ & 38 & 50,7 \\
$\quad$ Perempuan & 37 & 49,3 \\
Usia & & \\
$\quad>6$ bulan -1 tahun & 19 & 25,3 \\
$\quad>1$ tahun $-<2$ tahun & 56 & 74,7 \\
\hline
\end{tabular}

\section{Hubungan asupan gizi dengan stunting}

Deskripsi hubungan asupan gizi dengan stunting Tabel 2 menunjukkan bahwa proporsi baduta yang memiliki asupan gizi lebih tinggi pada kelompok responden berstatus gixi stunting, namun proporsi baduta berasupan gizi cukup banyak ditemukan pada kelompok responden berstatus gizi normal. Hasil uji statistik menunjukkan bahwa ada hubungan yang bermakna antara asupan gizi dengan stunting.

\section{Hubungan Pemberian ASI dengan stunting}

Deskripsi hubungan asupan gizi dengan stunting Tabel 2 menunjukkan bahwa proporsi baduta yang tidak diberi ASI eksklusif lebih banyak pada kelompok stunting. Hasil uji statistik menunjukkan bahwa ada hubungan yang bermakna antara asupan gizi dengan stunting ( $p$ value $=0,000$ $<0,05)$ dan odd ratio 46.

\section{Hubungan pemberian ASI dengan stunting}

Deskripsi hubungan pemberian ASI eksklusif dengan stunting dapat dilihat pada Tabel.1. Baduta yang tidak mendapatkan ASI eksklusif banyak terdapat pada kelompok baduta berstatus gizi stunting $(78,1 \%)$, sedangkan kelompok baduta berstatus gizi normal $(21,8 \%)$ seluruhnya diberi ASI eksklusif. Hasil uji statistik menunjukkan ada hubungan yang bermakna antara pemberian ASI eksklusif dengan stunting ( $p$ value $=0,000<0,05$ ) dan odd ratio 0,2 . 
Tabel 2. Analisis determinan stunting

\begin{tabular}{|c|c|c|c|c|c|c|c|}
\hline \multirow{3}{*}{ Variabel } & \multicolumn{4}{|c|}{ Status Gizi } & \multirow{3}{*}{$\chi^{2}$} & \multirow{3}{*}{$\mathbf{p}$} & \multirow{3}{*}{$\begin{array}{c}\text { OR } \\
\text { (CI 95\%) }\end{array}$} \\
\hline & \multicolumn{2}{|c|}{ Stunting } & \multicolumn{2}{|c|}{ Normal } & & & \\
\hline & $\mathbf{F}$ & $\%$ & $\mathbf{F}$ & $\%$ & & & \\
\hline \multicolumn{8}{|l|}{ Asupan gizi } \\
\hline Kurang & 46 & 90,2 & 5 & 9,8 & \multirow{2}{*}{36,4} & \multirow{2}{*}{0,000} & 46 \\
\hline Cukup & 4 & 16,7 & 20 & 83,9 & & & $11,16-189,49$ \\
\hline \multicolumn{8}{|l|}{ Pemberian ASI } \\
\hline Tidak eksklusif & 50 & 78,1 & 14 & 21,9 & \multirow{2}{*}{22,38} & \multirow{2}{*}{0,000} & 0,21 \\
\hline Eksklusif & 0 & 0 & 11 & 100 & & & $0,139-0,34$ \\
\hline \multicolumn{8}{|l|}{ Berat bayi lahir } \\
\hline BBLR & 6 & 100 & 0 & 0 & \multirow{2}{*}{3,26} & \multirow{2}{*}{0,079} & 1,5 \\
\hline Normal & 44 & 63,8 & 25 & 36,2 & & & $1,31-1,187$ \\
\hline \multicolumn{8}{|l|}{ Penyakit infeksi } \\
\hline Penderita & 44 & 73,3 & 16 & 26,7 & \multirow{2}{*}{6,0} & \multirow{2}{*}{0,029} & 4,12 \\
\hline Bukan penderita & 6 & 40,0 & 9 & 60,0 & & & $1,26-13,4$ \\
\hline
\end{tabular}

\section{Hubungan berat bayi lahir dengan stunting}

Deskripsi hubungan berat bayi lahir dengan stunting dapat dilihat pada Tabel 2. Baduta yang memiliki riwayat BBLR lebih banyak terdapat pada kelompok stunting $(100 \%)$, sedanglan baduta dengan riwayat berat badan normal lebih banyak pada kelompok berstatus gizi normal. Hasil uji statistik menunjukkan bahwa tidak ada hubungan yang bermakna antara BBLR dengan stunting ( $\mathrm{p}$ value $=0,079>0,05)$ dan odd ratio 1,5.

\section{Hubungan penyakit infeksi dengan stunting}

Deskripsi hubungan penyakit infeksi dengan stunting dapat dilihat pada Tabel 2. Baduta yang menderita penyakit infeksi banyak terdapat pada kelompok baduta stunting $(73,3 \%)$, sedangkan baduta yang tidak menderita penyakit infeksi banyak terdapat pada kelompok baduta normal $(60 \%)$. Hasil uji statistik menunjukkan ada hubungan yang bermakna antara penyakit infeksi dengan stunting $(p=0,029<0,05)$ dan odd ratio 4,1 .

\section{BAHASAN}

\section{Hubungan asupan gizi dengan stunting}

Hasil uji statistik antara asupan gizi dengan stunting menunjukkan ada hubungan yang signifikan ( $p$-value 0,000) Tabel 2. Penelitian ini sejalan dengan hasil penelitian Fitri pada tahun 2012 yang menunjukan ada hubungan yang signifikan antara asupan gizi dengan kejadian stunting pada baduta di Wilayah Sumatera dengan proporsi kejadian stunting pada baduta lebih banyak ditemukan pada kelompok dengan asupan gizi kurang $(39,7 \%)$ dibandingkan baduta dengan asupan gizi cukup $(35,2 \%)(7)$. Namun demikian, hasil penelitian ini berbeda dengan penelitian Aridiyah pada tahun 2015 yang menyebutkan bahwa tidak terdapat hubungan yang signifikan antara asupan gizi (kecukupan energi) dengan kejadian stunting pada anak balita di wilayah pedesaan (Puskesmas Kalisat) dan daerah perkotaan (Puskesmas Patrang dan Mangli) di Kabupaten Jember Provinsi Jawa Timur, selanjutnya dari hasil penelitian tersebut juga disebutkan bahwa tingkat kecukupan protein dan kalsium tidak memiliki hubungan yang signifikan dengan stunting (8).

Pola makan anak tidak terpenuhi akan menyebabkan stunting. Oleh kerena itu, asupan zat gizi sangat diperlukan untuk membantu pertumbuhan dan perkembangan. Pola makan yang sehat dan bergizi juga dapat mempengaruhi pertumbuhan dan perkembangan motorik pada anak. Pola makan sehat yang dimaksud meliputi jenis makan yang bergizi, frekuensi makan yang diperhatikan, serta porsi makan yang dikonsumsi anak. Kebutuhan dan asupan gizi berasal dari konsumsi makanan sehari-hari (9).

Stunting sangat sering dialami oleh anakanak yang berpola makan yang tidak baik ditambah lagi waktu yang tidak teratur dalam mengonsumsi 
makanan menyebabkan asupan gizi anak tidak maksimal. Anak-anak yang aktif lebih banyak memerlukan nutrisi untuk proses pertumbuhannya menjadi lebih baik dan terhindar dari stunting. Apabila anak tidak aktif dan pemenuhan nutrisinya kurang baik sangat berisiko menyebabkan anakanak mengalami stunting (9) .

Hasil penelitian sebelumnya mengenai suplementasi makanan pada anak-anak di negara berkembang telah menunjukkan sedikit efek atau perubahan pada berat dan tinggi badan. Penelitian tersebut menjelaskan bahwa walaupun telah disediakan makanan yang berenergi tinggi pada anakanak di negara berkembang, anak-anak tetap menolak makanan tersebut dikarenakan faktor anoreksia yang disebabkan infeksi, kekurangan zat gizi tertentu, dan konsumsi makanan yang tidak seimbang (11).

Hasil wawancara dengan responden pada penelitian ini menjelaskan bahwa baduta yang stunting dipengaruhi oleh beberapa faktor, di antaranya: frekuensi dan jumlah pemberian makan, densitas energi yang rendah, nafsu makan berkurang karena konsumsi makan yang tidak bervariasi, dan penyakit infeksi. Hasil penelitian menjelaskan bahwa kurangnya asupan gizi anak yang stunting disebabkan oleh makanan yang tidak beragam, seperti anak yang tidak suka minum susu, makan buah dan sayur-sayuran. Keterangan lain dari responden menyebutkan bahwa anak juga sering mengonsumsi mie instan serta jajanan yang tidak sehat.

\section{Hubungan pemberian ASI dengan kejadian stunting}

Hasil uji chi-square $\left(\mathrm{X}^{2}\right)$ menunjukan hubungan antara pemberian ASI dengan stunting $p$-value 0,000 (Tabel 2). Kegagalan pemberian ASI Eksklusif disebabkan oleh rendahnya pemahaman ibu tentang manfaat pemberian ASI pada anak, serta rendahnya kesadaran keluarga akan pentingnya ASI eksklusif. Namun hasil penelitian ini berbanding terbalik dengan hasil penelitian yang telah dilakukan oleh Suyatno (2009) yang mengungkapkan bahwa tidak dijumpainya korelasi yang bermakna antara pemberian ASI dengan perubahan skor simpang baku indeks status gizi BB/U, TB/U, dan BB/TB, disebabkan pada bulan-bulan awal kehidupan seorang bayi ( $0-2$ bulan) keadaan pertumbuhan linier dan pertumbuhan masa lunak berjalan seimbang (12).

Penelitian ini juga sejalan dengan penelitian yang dilakukan oleh Lestari di Aceh tahun 2014 yang menjelaskan bahwa proporsi anak stunting lebih tinggi terjadi pada anak yang tidak diberi ASI eksklusif dan MPASI diberikan terlalu dini. Hal ini terlihat dari nilai OR yang sama. Ada hubungan antara ASI eksklusif dan umur pemberian MP-ASI (13).

\section{Hubungan bayi berat lahir rendah dengan stunting}

Hasil analisis uji statistik chi-square $\left(\chi^{2}\right)$ hubungan antara berat bayi lahir rendah dengan stunting diperoleh hasil $p$-value 0,079 , sehingga dapat disimpulkan bahwa tidak ada hubungan yang signifikan antara bayi berat lahir rendah dengan stunting (Tabel 2). Hal ini disebabkan proporsi rata-rata perbandingan berat bayi lahir, baik yang stunting maupun yang normal tidak jauh berbeda. Perbandingan tersebut dapat dipengaruhi oleh status gizi ibu pada saat hamil yang cukup baik.

Hasil penelitian ini tidak sejalan dengan penelitian Rahayu di Hulu Sungai Utara tahun 2015 yang menyebutkan bahwa ada hubungan antara berat badan saat lahir dengan stunting dan diperoleh ada sebanyak $39,3 \%$ balita yang tidak BBLR yang status gizi stunting dan $51,35 \%$ normal (14). Penelitian ini juga tidak sejalan dengan penelitian Fitri menyebutkan bahwa berat lahir secara bermakna berhubungan dengan kejadian stunting (7) .

Penelitian yang dilakukan oleh Nadiyah pada tahun 2014 menyebutkan bahwa bayi dengan berat lahir normal banyak terdapat pada kelompok status gizi normal $(67,3 \%)$, sedangkan bayi yang stunting pada kelompok tersebut hanya sebesar $32,7 \%$. Uji statistik penelitian tersebut menunjukkan nilai $p=$ 0,044 , sehingga dapat disimpulkan ada hubungan antara berat lahir bayi dengan stunting (15). Stunting merupakan dampak dari growth faltering atau kegagalan pertumbuhan. Hal tersebut juga dapat mengakibatkan penurunan staus gizi anak (underweight) yang pada umumnya terjadi dalam periode yang singkat pada awal kehidupan (sebelum 
lahir hingga usia kurang lebih umur 2 tahun). Gangguan pertumbuhan tersebut akan menjadi masalah yang serius di kemudian hari dan dampak yang ditimbulkan di antaranya dapat mengakibatkan penurunan produktivitas kerja pada anak laki-laki yang pada akhirnya berpengaruh terhadap status ekonomi. Gangguan pertumbuhan (stunting) pada anak perempuan dapat meningkatkan risiko melahirkan bayi dengan berat lahir rendah (16).

\section{Hubungan penyakit infeksi dengan stunting}

Berdasarkan hasil penelitian diketahui bahwa penyakit infeksi berhubungan dengan kejadian stunting pada baduta ( $p$-value 0,029). Hal ini berarti penyakit infeksi merupakan salah satu faktor penyebab stunting. Hal ini sejalan dengan penelitian yang dilakukan oleh Masithah, Soekirman \& Martianto di Desa Mulya Harja pada tahun 2005 yang dilaporkan riwayat penyakit diare dan infeksi saluran penafasan merupakan faktor risiko kejadian stunting. Anak yang sering mengalami diare akut berisiko 2,3 besar tumbuh menjadi stunting (17).

Penyakit infeksi mempunyai efek substansial terhadap pertumbuhan anak. Penyakit infeksi juga berhubungan dengan gangguan pertumbuhan. Hasil penelitian Picauly juga menemukan bahwa penyakit infeksi merupakan faktor risiko kejadian stunting (18). Anak yang memiliki riwayat penyakit infeksi berpeluang lebih besar mengalami stunting 2,3 kali lebih besar dibandingkan dengan yang tidak memiliki riwayat penyakit infeksi. Hasil wawancara pada penelitian tersebut didapatkan hasil penyakit infeksi yang banyak dialami oleh anak adalah diare. Durasi kejadian diare yang dialami anak rata-rata selama 1-2 hari, sehingga mempengaruhi nafsu makan anak dan mempengaruhi kenaikan berat berat badan. Penyakit infeksi lainya yang banyak diderita oleh anak berdasarkan hasil penelitian yaitu panas, batuk, pilek, dan cacingan.

Hal ini sejalan dengan penelitian Kusumawati di Banyumas pada tahun 2015, berdasarkan hasil analisis multivariate dari penelitian tersebut di jelaskan bahwa diketahui dari faktor anak, ditemukan persentase kasus lebih banyak memiliki riwayat BBLR, memiliki riwayat panjang badan lahir rendah (kurang dari 48 sentimeter), mempunyai riwayat kurang baik dalam pemberian ASI dan MP-ASI, sering mengalami penyakit infeksi, serta kurang mendapatkan pelayanan kesehatan yang baik dan imunisasi. Hasil uji statistik penelitian ini menunjukkan bahwa anak yang sering menderita penyakit infeksi 8,8 kali lebih besar berisiko mengalami stunting (19). Namun hasil penelitian ini berbeda dengan penelitian yang dilakukan oleh Anisa tahun 2012 yang menjelaskan bahwa tidak terdapat hubungan antara penyakit infeksi (diare dan ISPA) dengan kejadian stunting pada balita di Kelurahan Kalibaru Depok Jawa Barat (20).

Penyakit infeksi merupakan infeksi yang umum terjadi dan mudah menular pada anak. Infeksi yang terjadi juga tergolong ringan, disertai batuk pilek berlangsung selama 2-3 hari. Infeksi saluran pernafasan atas dapat sembuh dengan sendirinya dalam waktu yang singkat dan pada penelitian ini gejala infeksi pernafasan yang terjadi mungkin tidak dapat mempengaruhi nafsu makan sehingga tidak sampai menurunkan status gizi anak (21).

\section{KESIMPULAN DAN SARAN}

Pada penelitian ini ditemukan ada hubungan yang bermakna antara asupan gizi, pemberian ASI eksklusif, penyakit Infeksi dengan stunting pada baduta, dan tidak ada hubungan yang bermakna antara bayi berat lahir rendah dengan stunting pada baduta di Wilayah Kerja Puskesmas Ulim Kabupaten Pidie Jaya.

Berdasarkan hasil penelitian, saran yang diberikan yaitu bagi instansi terkait di bidang kesehatan diharapkan agar lebih meningkatkan peran tenaga kesehatanuntuk memberikan pemahaman kepada masyarakat tentang pentingnya pemberian ASI eksklusif, pemenuhan nutrisi anak dengan mengatur asupan gizi yang baik, jumlah kalori dan protein yang cukup serta jadwal frekuensi makan yang teratur dapat membantu proses pemenuhan gizi menjadi lebih baik

\section{RUJUKAN}

1. Gibson RS. Principles of Nutritional Assessment. Second Edition. New York: Oxford University Press. Inc.; 2005. 
2. Satria. Sepertiga Anak Usia Sekolah di Indonesia Alami Stunted [Internet]. 2010 [cited 2015 Nov 10]. Available from: https://ugm.ac.id/ id/berita/2663-sepertiga.anak.usia.sekolah. di.indonesia.alami.stunted

3. Nuryati S. 37 Persen Anak Indonesia Kerdil. Sumber: Sinar Harapan, Prakarsa Rakyat [Internet]. 2008 [cited 2015 Nov 10]. Available from: www.prakarsa-rakyat.org

4. Riset Kesehatan Dasar. Laporan Riset Kesehatan Dasar Riskesdas 2013. Jakarta: Badan Penelitan dan Pengembangan Kementerian Kesehatan $\mathrm{RI} ; 2013$.

5. Dinas Kesehatan Kabupaten Pidie. Laporan status gizi balita. Pidie Jaya: Dinas Kesehatan Kabupaten Pidie Jaya; 2015.

6. Aramico B, Amin FA, Novita R. Hubungan pemberian ASI eksklusif, pengetahuan, pendapatan dan pola asuh dengan tumbuh kembang anak balita di Desa Lie, Kota Banda Aceh. J Kesehat Masy Aceh. 2016;2(1):71-9.

7. Fitri. Berat lahir sebagai faktor dominan terjadinya stunting pada balita (12-59 bulan) di Sumatera (analisis data rikesdas 2010). Universitas Indonesia; 2012.

8. Aridiyah FO, Rohmawati N, Ririanty M. Faktorfaktor yang Mempengaruhi Kejadian Stunting pada Anak Balita di Wilayah Pedesaan dan Perkotaan (The Factors Affecting Stunting on Toddlers in Rural and Urban Areas). Pustaka Kesehat. 2015;3(1):163-70.

9. Dian M, Hakim L, Haryani S, Arif NS, Kep S, Program $\mathrm{M}$, et al. Hubungan pola makan bergizi dengan tumbuh kembang motorik pada anak usia sekolah di SD Tawang Mas 02 Semarang. STIKES Telogorejo Semarang; 2012.

10. Afriana R. Hubungan pola konsumsi makan terhadap status gizi anak kelas 6 di SDN 13 Kelapa Dua Tangerang Tahun Ajaran 20102011. Universitas Pembangunan Nasional; 2011.

11. Hermina, Prihatini S. Gambaran keragaman makanan dan sumbangannya terhadap konsumsi energi protein pada anak balita pendek (stunting) di Indonesia. Bul Penelit Kesehat. 2011;39(2):62-73.

12. Suyatno, Ummi S. Riset kebidanan metodologi dan aplikasi. Yogyakarta: Mitra Cendekia; 2009.

13. Lestari W, Margawati A, Rahfiludin Z. Faktor risiko stunting pada anak umur 6-24 bulan di kecamatan Penanggalan kota Subulussalam provinsi Aceh. J GIZI Indones. 2014;3(1):37-45.

14. Rahayu A, Yulidasari F, Putri AO, Rahman F. Riwayat Berat Badan Lahir dengan Kejadian Stunting pada Anak Usia Bawah Dua Tahun. Kesmas Natl Public Heal J. 2015 Nov 8;10(2):67.

15. Nadiyah, Briawan $D$, Martianto D. Faktor risiko stunting pada anak usia 0-23 bulan di Provinsi Bali, Jawa Barat, dan Nusa Tenggara Timur. J Gizi dan Pangan. 2014;9(2):125-32.

16. Kusharisupeni. Growth faltering pada bayi di Kabupaten Indramayu Jawa Barat. MAKARA Kesehat. 2002;6(1):1-5.

17. Masithah T, Soekirman I, Martianto D. Hubungan pola asuh makan dan kesehatan dengan status gizi anak batita di Desa Mulya Harja. Media Gizi Kel. 2005;29(2):29-39.

18. Picauly I, Toy SM. Analisis determinan dan pengaruh stunting terhadap prestasi belajar anak sekolah di Kupang Dan Sumba Timur, NTT. J Gizi dan Pangan. 2013;8(1):55-62.

19. Kusumawati E, Rahardjo S, Sari HP. Model Pengendalian Faktor Risiko Stunting pada Anak Bawah Tiga Tahun. Kesmas Natl Public Heal J. 2015;9(3):249-56.

20. Anisa P. Faktor - faktor yang berhubungan dengan kejadian stunting pada balita usia 25 - 60 bulan di Kelurahan Kalibaru Depok Tahun 2012. Universitas Indonesia; 2012.

21. Wahdah S. Faktor risiko kejadian stunting pada anak umur 6-36 bulan di wilayah pedalaman Kecamatan Silat Hulu Kabupaten Kapuas Hulu Provinsi Kalimantan Barat. Universitas Gadjah Mada; 2012. 